\title{
DIFFERENTIATION AND NUMERICAL ANALYSIS OF ORAL YEASTS BASED ON SDS-PAGE PROFILES. INFLUENCE OF THE CULTURE MEDIA ON THE WHOLE-CELL PROTEIN EXTRACTS
}

\author{
HÖFLING, J. F., ROSA, E. A. R., PEREIRA, C. V., BORIOLLO, M. F. G. and RODRIGUES, J. A. O. \\ Laboratório de Microbiologia e Imunologia, Departamento de Diagnóstico Oral, Faculdade de Odontologia \\ de Piracicaba, Unicamp, SP, Brazil \\ Correspondence to: José Francisco Höfling, Laboratório de Microbiologia e Imunologia, \\ Departamento de Diagnóstico Oral, Faculdade de Odontologia de Piracicaba, Unicamp, Av. Limeira, 901, C.P. 52, \\ CEP 13414-900, Piracicaba, SP, Brazil, e-mail: hofling@ fop.unicamp.br \\ Received March 1 ${ }^{\text {st }}, 1999$ - Accepted May 28, 1999 - Distributed August 31, 2001
}

(With 4 figures)

\begin{abstract}
The application of gel electrophoresis and numerical analysis of yeast soluble proteins analysis to the investigation of 12 oral yeast strains belonging to five species is described. It involves one-dimensional electrophoresis of SDS-solubilized whole-cell proteins using different culture media for the cultivation of the cells, integration densitometries in the areas of the gels and percentages of the proteins extraction. These extracts were prepared from four isolates of Candida albicans, two of $C$. tropicalis, $C$. guilliermondii, C. parapsilosis and C. krusei. The extracts from whole-cells proteins using different culture media for the cultivation of the cells were fractionated by slab electrophoresis using a discontinuous buffer system. The corresponding patterns showed at least 36 polypeptides in the range of 14.4-200 kDa. Different isolates of each species were clearly different in each of the five species. The data obtained suggest that different nutritional compositions led to the expression of different proteins derived from alternatives metabolic pathways expressed by the electrophoretic profiles. The construction of a database of protein fingerprints and numerical analysis based on such data, may have some implications in the classification and identification of such species with epidemiological, ecological and taxonomic purposes. A well defined or synthetic culture media seems to be much properly.
\end{abstract}

Key words: oral yeasts, SDS-Page, numerical analysis, differentiation, protein extracts, culture media.

\section{RESUMO}

\section{Proteínas de células totais de leveduras SDS-Page e análise numérica}

Neste trabalho são descritas a aplicação de gel de poliacrilamida e a análise numérica no estudo de proteínas solúveis na investigação de 12 amostras de leveduras orais, pertencentes a 5 espécies. Aplicouse a técnica de eletroforese em gel de poliacrilamida na análise de proteínas de células totais, usando-se diferentes tipos de meios de cultura de células leveduriformes; densitometria de integralização da área dos géis, com a porcentagem de extração das proteínas para cada amostra de meio de cultura; além dos respectivos dendrogramas comparativos. Foram preparados extratos a partir de quatro isolados de $C$. albicans, dois de C. tropicalis, $C$. guilliermondi, $C$. parapsilosis e $C$. krusei. Os extratos foram fracionados por eletroforese em gel de acrilamida (slab), usando o sistema de tampão descontínuo. Os padrões de bandas protéicas mostraram pelo menos 36 polipeptídios entre 14.4-200 kDa. Dentre os diversos isolados de cada espécie, observaram-se diferenças significativas em cada uma das cinco espécies estudadas. Os dados obtidos sugerem que diferentes composições nutricionais presentes nos meios determinam a expressão de diferentes proteínas, derivadas de mecanismos metabólicos alternativos, expressos nos perfis eletroforéticos. A construção de um banco de dados de proteínas e a análise numérica com base em dados 
dessa natureza podem ter implicações na diferenciação de espécies, com objetivo epidemiológico, ecológico e taxonômico. Meios nutricionalmente definidos ou sintéticos seriam mais apropriados.

Palavras-chave: leveduras orais, SDS-Page, análise numérica, diferenciação, extratos protéicos, meios de cultura.

\section{INTRODUCTION}

The Fungi, especially yeasts belonging to the genus Candida are potentially pathogenic agents. They are capable of inducing to many pathologies on the living organisms acting as opportunists. With the AIDS advent, researches using such microorganisms have increased in the physiological, biochemical and serological aspects (Davemport, 1970; Axelsen, 1973; Faux et al., 1975; Greenfield \& Jones, 1981; Dreizen, 1984; Gatermann et al., 1986; Brondz \& Olsen, 1991; Allen, 1992; Challacombe, 1994). In the oral cavity, they are responsible for pathologies affecting buccal structures and justify the increase of clinical cases and investigations on such area.

The form-genus Candida includes a heterogeneous group of 81 asporogeneous yeast species (Van Uden \& Buckley, 1970). Candida species in addition to forming yeast-like budding cells, have the ability to produce pseudo mycelium and true mycelium (Ajello et al., 1963). Conventional methods for the classification of Candida species are based particularly on morphological and physiological features. During the last years, several specific techniques has been developed and applied to taxonomic studies of such organisms, as the analysis of the electrophoretic profiles of soluble proteins (Fregerslev, 1969) and isoenzymes (Berchev \& Izimirov, 1967), serological features (Tsuchiya $e t$ al., 1965; Biguet et al., 1962; Rimbaud et al., 1966), proton magnetic resonance (PMR) spectra of mannans and mannose-containing polysaccharides (Spencer \& Gorin, 1969, 1971), immunoelectrophoretic studies of antigens (Gabriel-Bruneau \& Guinet, 1984; Biguet et al., 1962; Manning \& Mitchell, 1980), chromosomal DNA banding patterns (Viljoen et al., 1989; Magee \& Magee, 1987), assessment of basesequence homology by means of DNA-RNA hybrid experiments (Landau et al., 1968) and long-chain fatty acid analyses (Viljoen \& Koch, 1989; Viljoen et al., 1989).

One-dimensional gel electrophoresis (SDSPage) of proteins, combined with computerized analysis of patterns, has been used increasingly in microbial Systematics (Barns et al., 1991; Hall, 1969;
Hall et al., 1969; Johnston et al., 1988; Jordan, 1994; Magee et al., 1988; Meyer et al., 1993; Okiri \& Kawamoto, 1995). Protein patterns offer considerable potential for typing strains of clinical interest and for taxonomic purposes, especially for the studies of biodiversity quantification among microorganisms (O’ Donnell et al., 1994; Barns et al., 1991; Blignant \& Koch, 1992; Booth, 1979). In this sense, the delineation of the electrophoretic profiles of the yeast extracts have demonstrated that a database of SDS-Page-protein patterns provides a valuable tool for the identification of such microorganisms. The analysis of the protein profiles has been used to build phenograms showing the protein electrophoretic relationship among all the strains studied with taxonomic and systematic purpose.

The literature data are based in studies using most of the time a specific culture media for the cultivation of the cells. Nevertheless, studies using different types of culture media has not been done. The purpose of this study was to compare the electrophoretic profiles of some oral Candida species through the analysis of the protein profiles of yeast cells extracts grown on different culture media and to evaluate their implications for taxonomic purposes by the comparative numerical analysis data.

\section{MATERIAL AND METHODS}

\section{Strains used}

A total of 12 strains of 5 Candida different yeast species (C. albicans, $C$. tropicalis, $C$. guilliermondii, C. parapsilosis and C. krusei) were investigated. All strains were isolated from healthy patients of Dental Clinic, School of Dentistry, Unesp, São José dos Campos, by courtesy of Dr. Olavo C. Jorge.

\section{Cell cultivation}

Cultures were grown on different liquid culture media as, 1. yeast complete medium (YCM) (per $500 \mathrm{ml}$ of distilled water: $5 \mathrm{~g}$ neopeptone, $5 \mathrm{~g}$ yeast extract, $0.25 \mathrm{~g} \mathrm{KH}_{2} \mathrm{PO}_{4}, 10 \mathrm{~g}$ glucose); 2 . sabouraud maltose (SM), (5 g neopeptone, $20 \mathrm{~g}$ maltose); 3. sabouraud dextrose (SD), $5 \mathrm{~g}$ peptone, $20 \mathrm{~g}$ 
dextrose); 4. pagano levin (PL) (5 g peptone, $0.5 \mathrm{~g}$ yeast extract, $20 \mathrm{~g}$ dextrose, added of $50 \mathrm{mg}$ of chloride 2, 3, 5 tripheniltetrazolium plus $500 \mathrm{mg}$ of neomicin/ml); 5. fungi selective (FS) (per 1,000 ml of distilled water: $10 \mathrm{~g}$ soya peptone, $10 \mathrm{~g}$ dextrose, $0.4 \mathrm{~g}$ cycloheximide, $0.05 \mathrm{~g}$ chloramphenicol); 6 . bromocresol candida (BCG) (10 g peptone, $1 \mathrm{~g}$ yeast extract, $40 \mathrm{~g}$ dextrose, $0.02 \mathrm{~g}$ bromocresol green, $\mathrm{pH}$ 6.1-6.2 added of $500 \mathrm{mg}$ of neomicin/ $\mathrm{ml}$ ), were incubated in a shaking machine at $37^{\circ} \mathrm{C}$. The cells were harvested at logaritmic growth phase and washed three times in $0.85 \%$ sterile saline solution.

\section{Cell-free extracts preparation}

Yeast cells (200 mg $+500 \mathrm{ml}$ of distilled water) maintained in liquid nitrogen $\left(-196^{\circ} \mathrm{C}\right)$, were powdered for three minutes (Gomes, 1995), centrifuged at $3,000 \times \mathrm{g}$ for 5 minutes and the supernatants were stored at $-80^{\circ} \mathrm{C}$. The preparation of the proteins for electrophoresis was made according to Bruneau \& Guinet (1989) method.

\section{Protein electrophoresis}

One-dimensional SDS-Page were performed according to described by Laemmli (1970), in a discontinuous gel system. The final polyacrylamide gels concentrations were $12.5 \%(\mathrm{w} / \mathrm{v})$ for the running gel and $4.5 \%$ (w/v) for the stacking gel. Further details of the methods used in gel preparation and electrophoresis were described previously (Moore et al., 1980).

\section{Comparison of the electrophoretic patterns}

SDS-Page gels (thickness $1 \mathrm{~mm}$ ) with acrylamide concentrations ranging from $10 \%$ to $14 \%$ were tested. After stainin, gels were examined visually to ascertain the presence of characteristic differentiating bands for the various species. The optimum acrylamide concentration to differentiate the species was $12.5 \%$. The whole-cell protein profiles of all the strains grown in different media were visually differentiated by a number and position of major protein bands in the molecular weight range 14.4-200 kDa.

\section{Integration densimetries and protein extraction percentages}

The electrophoresis standards data provided diagrams (Fig. 1) and were treated computationally which generated graphs of the respective gels integration densimetries with the protein percentages extraction for each sample of the cultivate media.

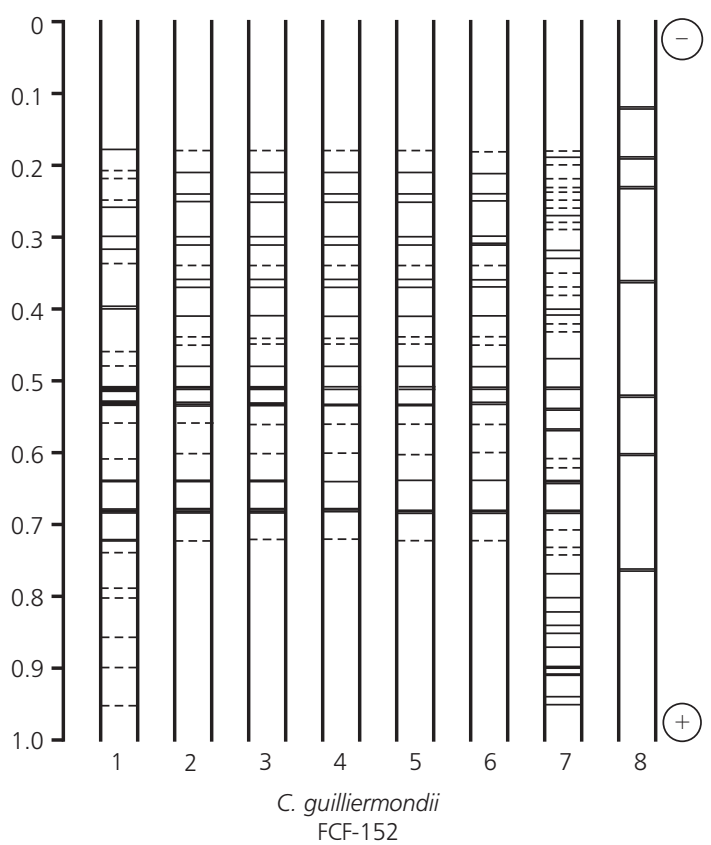

Sample FCF-152 of Candida guilliermondii (lines 1 to 6), Saccharomyces cerevisae (line 7), protein standard BIORAD 161.0317 (line 8).

Fig. 1 - General diagram of the electrophoresis SDS-Page standard.

\section{RESULTS}

SDS-Page of 12 strains yeast extracts studied produced Coomassie blue staining protein patterns containing up to 36 distinct bands, with 3-6 major bands (Figs. 2 and 3). The components ranged in molecular weight from about 14.4 to $200 \mathrm{kDa}$ in such $12.5 \%$ homogeneous separating gels. Each species produced a characteristic band pattern easily identified by the position of the major protein bands.

The patterns were reproducible for the replicates of the strains in diferent gels, with electrophoretic mobilities do not showing variations greater than \pm 0.2 , for $\mathrm{Rf}$ values. Similarities and differences among the patterns in respect to the number and electrophoretic mobility of protein fractions are shown. The isolates of each species generated different patterns and, in most instances, the differences among the isolates were clearly evident. The different protein concentrations data are shown in the Table 1 and a high variability in the respective areas of the SDS-Page gels densitometries integralization were detected. The grouping of Candida isolates derivated from 
numerical analysis of the electrophoretic data showed a high level of differentiation among all the species by using different culture media for the cultivation of the cells (Fig. 4).

\section{DISCUSSION}

The main criteria used in fungal taxonomy has been the way of the reproductive structure and the manner in which these structures develop (Glynn $\&$ Reid, 1969). These authors stated that the precise identification of fungi, both in culture and in natural substrates, is frequently impossible because of the absence of such reproductive structures. Also, doubts whether the nature of the reproductive units formed are normal; that is, whether the conditions under which the fungus has grown are similar to that found under "natural conditions".
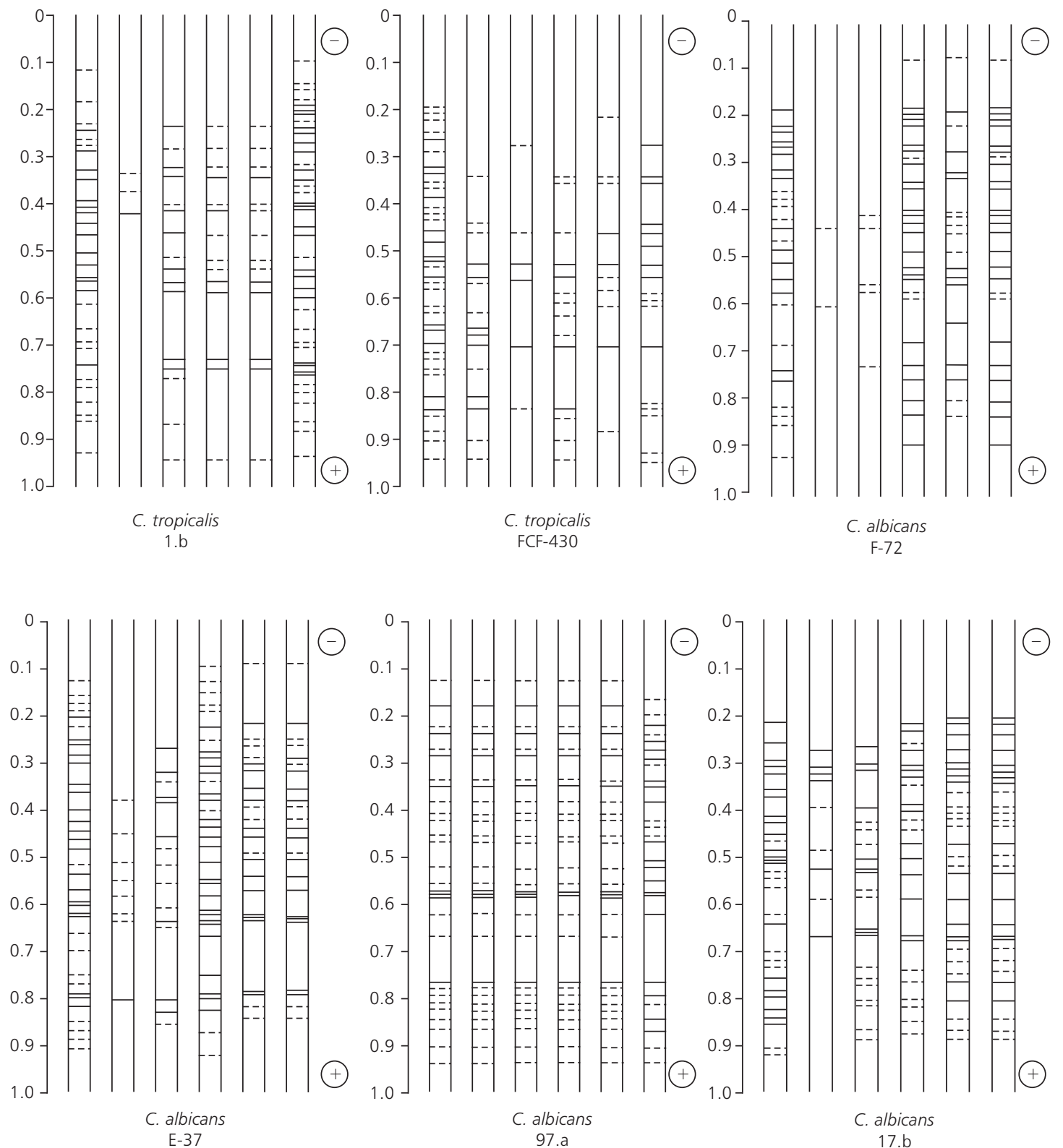

Fig. 2 - Whole-cell protein profiles of yeast strains on Coomassie blue-stained, 12.5\% SDS-polyacrylamide gel using different culture media for the cultivation of the cells. From left to right: YCM, SM, SD, PL, FS and BCG. 

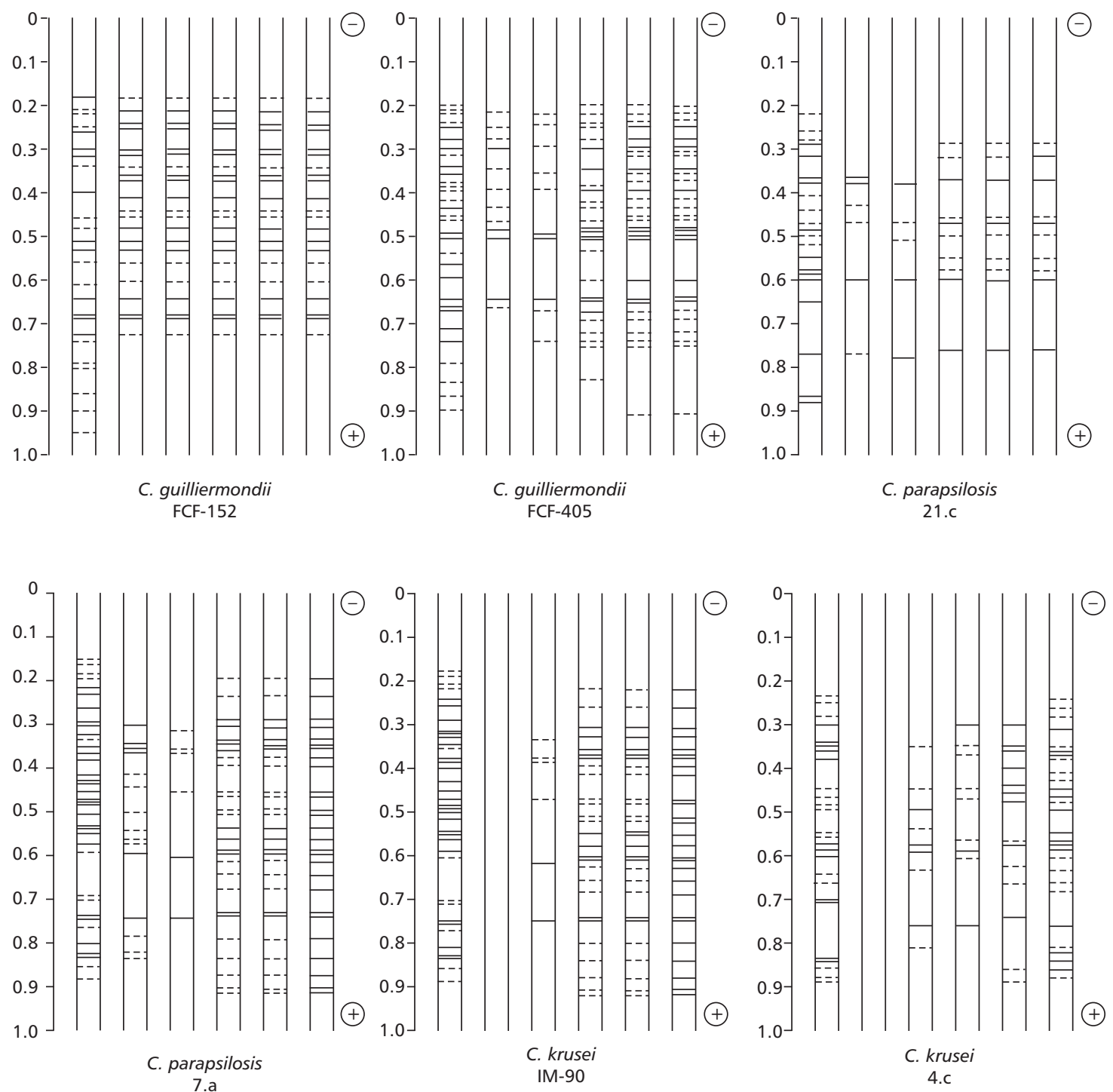

Fig. 3 - Whole-cell protein profiles of yeast strains on Coomassie blue-stained, 12,5\% SDS-polyacrylamide gel using different culture media for the cultivation of the cells. From left to right: YCM, SM, SD, PL, FS and BCG.

They showed that since soluble proteins must reflect the physiological state of the cell, rather than morphological structure, it seems reasonable to expect some variation in the protein patterns obtained, depending on the physiological state of the cell at the time of harvesting.

Also, Fink (1970) demonstrated that the wildtype yeast strain S-288C of Saccharomyces cerevisiae had a doubling time of 90 minutes in YEPD medium and 120 minutes in minimal culture medium.
This author observed that a saturated YEPD culture contains approximately $4 \times 10^{8}$ cells $/ \mathrm{ml}$, whereas a saturated minimal medium culture contains approximately $8 \times 10^{7}$ cells $/ \mathrm{ml}$. One liter of YEPD culture yields approximately $17 \mathrm{~g}$ of cells, wet weight and one liter of minimal medium yields $3.4 \mathrm{~g}$ of cells.

The composition and the characteristics of the culture media used as a support for the cellular development, interfere in the extraction of the intracellular protein components of the yeasts. 
The diversified concentration of proteins showed in Fig. 3 followed by the high variability of the SDS-Page gel densitometries are in accordance of such statement. Early investigations made by Shechter (1973b), in an attempt to identify Candida species by comparative protein disc electrophoresis, found that results are highly dependent on culture conditions, the age of the cultures, and the morphological stage of the yeast strain studied. However, Vancanneyt et al. (1991, 1992) found that cells of a given strain, grown in two different flasks, have approximately the same range of reproducibility as the electrophoretic technique itself. Such reproducibility was not founded in our results.

The protein concentrations from the intracellular yeast components extractions, visualized by the electrophoretic profile and reinforced by the respective SDS-Page gel densitometries were quantifying different for the cultivate media used.
The electrophoretic data obtained showed different protein patterns among all the species when using different culture media for the cultivation of the cells (Fig. 2). Some possible explanations for this event are that precursors required for the synthesis of some proteins may be present in one medium and absent in other, or some enzymes just are formed in the presence of their specific substrate, yielding distincts protein profiles.

In our study, all the cultures were maintained in the same temperature conditions, agitation, time of incubation and photoperiod, in a way that the only variable was the culture media composition.

In the different eletroforegrams it can be observed large variations in the profiles, as quantitative referring to the number of bands, as qualitative varying in their respective positions (values of Rf). However, some strains presented similar electrophoregrams for extracts of more than one culture media, specially for pagano-levin, fungi selective agar and bacto candida bromophenol.

TABLE 1

Total protein concentration from Candida species cultivated in different culture media expressed in mg of protein/cell mass (g).

\begin{tabular}{|c|c|c|c|c|c|c|c|}
\hline \multirow{2}{*}{\multicolumn{2}{|c|}{ Strains }} & \multicolumn{6}{|c|}{ Culture media } \\
\hline & & YCM & SMA & SDA & PL & FSA & BCG \\
\hline \multirow{5}{*}{ 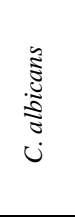 } & $97-\mathrm{a}$ & 51.82 & 84.77 & 16.48 & 22.99 & 17.71 & 19.12 \\
\hline & F-72 & 51.93 & 25.77 & 18.52 & 47.08 & 13.37 & 15.15 \\
\hline & E-37 & 27.67 & 16.09 & 22.11 & 17.88 & 15.50 & 19.19 \\
\hline & $17-b$ & 45.99 & 37.46 & 28.41 & 43.21 & 14.67 & 20.28 \\
\hline & average & $44.35 \pm 11.5$ & $41.02 \pm 30.4$ & $21.38 \pm 5.2$ & $32.79 \pm 14.5$ & $15.31 \pm 1.8$ & $18.44 \pm 2.2$ \\
\hline \multirow{3}{*}{ 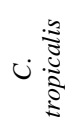 } & $1-b$ & 30.82 & 6.85 & 18.83 & 23.61 & 13.30 & 49.88 \\
\hline & FCF-430 & 35.66 & 44.51 & 6.29 & 18.69 & 9.52 & 10.15 \\
\hline & average & $33.24 \pm 3.4$ & $25.7 \pm 26.6$ & $12.56 \pm 8.9$ & $21.15 \pm 3.5$ & $11.41 \pm 2.7$ & $30.02 \pm 28.1$ \\
\hline \multirow{3}{*}{ 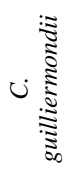 } & FCF-152 & 31.50 & 17.08 & 18.47 & 29.19 & 22.34 & 17.51 \\
\hline & FCF-405 & 36.49 & 36.39 & 15.66 & 47.75 & 0.87 & 16.43 \\
\hline & average & $33.99 \pm 3.5$ & $26.74 \pm 13.7$ & $17.07 \pm 2.0$ & $38.47 \pm 13.1$ & $11.60 \pm 15.2$ & $16.97 \pm 0.8$ \\
\hline \multirow{3}{*}{ 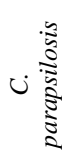 } & $21-c$ & 45.89 & 41.26 & 28.36 & 38.80 & 18.55 & 17.23 \\
\hline & $7-\mathrm{a}$ & 50.95 & 53.48 & 30.99 & 45.87 & 24.21 & 1.12 \\
\hline & average & $48.42 \pm 3.6$ & $47.37 \pm 8.6$ & $29.68 \pm 1.9$ & $42.33 \pm 5.0$ & $21.38 \pm 4.0$ & $9.18 \pm 11.4$ \\
\hline \multirow{3}{*}{$\frac{\tilde{v}}{\tilde{v}}$} & $1 \mathrm{M}-90$ & 30.99 & 31.84 & 23.36 & 7.62 & 16.70 & 18.51 \\
\hline & 4-c & 72.22 & 54.15 & 23.07 & 48.83 & 15.18 & 25.66 \\
\hline & average & $51.60 \pm 29.1$ & $42.99 \pm 15.8$ & $23.22 \pm 0.2$ & $28.22 \pm 29.1$ & $15.94 \pm 1.1$ & $22.10 \pm 5.0$ \\
\hline
\end{tabular}




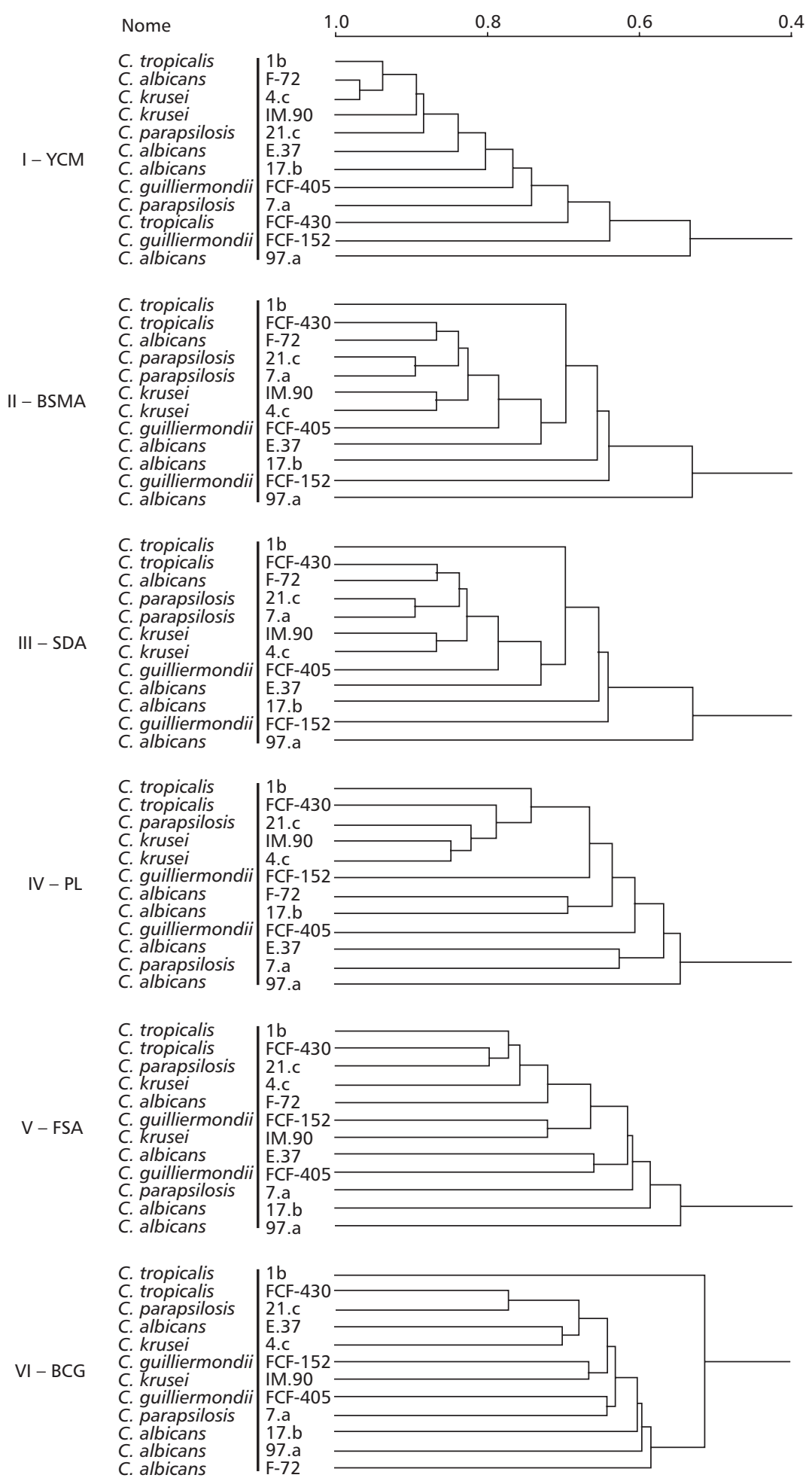

Fig. 4 - The protein electrophoretic relationships between 12 yeast strains using different culture medium for the cultivation of the cells. The correlation coefficient $r$ was used and clustering was achieved by the UPGMA method. Roman numerals indicate culture medium and respective individual phenograms. 
These media present, although in variable concentrations, the same sources of carbon (dextrose) and nitrogen (peptone). The largest variability observed in other culture media can be due to the different sources of carbon in the sabouraud dextrose agar and sabouraud maltose agar media, that implies in different mechanisms for the sugar processing.

Glynn \& Reid (1969) also observed that protein extracts obtained from Fusarium spp. mycelia, grown in two different culture media with no defined composition presented different electrophoretic profile as in the amount of bands as in their position. In our research with six different culture media with defined composition we observed similar behavior that furnished different electrophoretic profiles for each culture medium. The absence of a defined relationship among the protein fractions of a some species cultivated in different substrates indicates that the composition of these culture media may influence directly the electrophoretic profiles of the whole-cell proteins. The basic difference between this work and that published by Glynn \& Reid (1969) is that they used two different media, one of them rich in nutrients and other, called "minimum medium", that offers such nutrients in a very reduced concentration whereas we have valued six media with different qualitative and quantitative composition of nutrients. Other difference, is that the slab gels used by us in our electrophoresis allow better comparisons between two distinct isolates with superior discriminatory capacity (Ames, 1974).

Many papers has been published in last years on Candida classification using SDS-Page (Greenfield \& Jones, 1981; Monod et al., 1990; Brondz \& Olsen, 1991; Epstein et al., 1980; Lehmann et al., 1989; Shen et al., 1988). So, SDS-Page has been successfully used for classification and identification of many species of this group of microorganisms. The present investigation showed that the protein profile analysis of the extracts usually allows valid deductions for taxonomic purposes on microbial classification. The aim of this paper was to evaluate some possible electrophoretic variation among strains of a given species grown in different culture media. Although this technique be an useful and practical tool for screening multiple isolates for identification or to verify the authenticity of strains, once a database of reference protein electrophoregrams has been constructed or is available, the non-observation that culture conditions as well as other growing agents can be a limiting factor in this kind of research, will certainly induce to erroneous interpretations.

The groupings of Candida isolates derivated from numerical analysis of the electrophoretic data, showed a very different protein patterns among all the species by using different culture medium for the cultivation of the cells, suggesting that different nutritional compositions of the culture media led to the expression of different proteins derived from alternative metabolic pathways expressed by the electrophoretic profiles. When looking to the different phenograms most species are not delineated as separate entities. A considerable protein electrophoretic heterogeneity is observed among strains of single species. From the data presented it seems that SDS-Page is characterizing at the strain level (unique profiles are obtained for each individual strain). Consequently, no taxonomic conclusions can be draw at the species level.

According to Shechter (1973a), the value of numerical taxonomic classification in Candida will be determined by its capacity to incorporate new taxonomic characters and additional taxa rather than its concordance with existing classifications. The continuing accumulation of new biochemical and immunological characters in Candida will present more opportunities for application of numerical taxonomy.

Acknowledgments - We thank to all those graduate students and technicians of the Microbiology and Immunology and Laboratory which have been given their help to produce this research. It was supported by grant of the Faep/ Unicamp, n. 1005/92 to which we are very grateful.

\section{REFERENCES}

AMES, G. F. L., 1974, Resolution of bacterial proteins by polyacrylamide gel electrophoresis on slabs. J. Biol. Chem., 249(2): 634-644.

AJELlO, L., GEORG, L. K., KAPLAN, W. \& KAUFMAN, L., 1963, Laboratory manual for medical mycology. Public Health Service Publication, U. S. Government Printing Office, Washington, DC, n. 994, pp. EL-E28.

ALLEN, C. M., 1992, Oral candidiasis. Dental Abstracts, 37: 100. 
AXELSEN, N. H., 1973, Quantitative immunoeletrophoretic methods as tools for a polyvalent approach to standardization in the immunochemistry of Candida albicans. Infect. Immun, 7: 949-960.

BARNS, S. M., LANE, D. J., SOGIN, M. L., BIBEAU, C. \& WEISBURG, W. G., 1991, Evolutionary relationships among pathogenic Candida species and relatives. J. Bact., 173: 2250-2255.

BERCHEV, K. \& IZIMIROV, I., 1967, Isoenzymes of some oxido-reductases in the Candida genus as a basis of species identification after electrophoresis. Experientia, 23: 961-962.

BIGUET, J., TRAN VAN KY, P. \& ANDRIEU, S., 1962, Étude éléctrophorétique et immunochimique comparée des antigènes de quelques levures du genre Candida (C. albicans, C. stellatoidea, C. tropicalis, C. zeylanoides, C. krusei, C. pseudotropicalis, C. macedoniensis). Mycopathol. Mycol. Appl., 18: 239254.

BLIGNANT, E. \& KOCH, J. L. F., 1992, The presence of yeasts on carious and non-carious teeth. J. Dent. Res., 71: 961.

BOOTH, T., 1979, Strategies for study of fungi in marine and marine influenced ecosystems. Rev. Microbiol., 10: $123-138$

BRUNEAU, S. \& GUINET, R., 1989, Rapid identification of medically important yeasts by electrophoretic protein patterns, FEMS Microbiol, Lt., 58: 329-334.

BRONDZ, I. \& OLSEN, I., 1991, Review of chemosystematics: multivariate approaches to oral bacteria and yeasts. Acta Odontol. Scand., 50: 321-336.

CHALLACOMBE, S. J., 1994, Immunologic aspects of oral candidiasis. Oral Surg. Oral Med. Oral Pathol., 77: $202-210$

DAVEMPORT, J. C., 1970, The oral distribution of Candida in denture stomatitis. Brit. Dent. J., 130: 151-156.

DREIZEN, S., 1984, Oral candidiasis. Am. J. Med., 78: 28-33.

EPSTEIN, J. P., PEARSALl, N. N. \& TRUELOVE, E. L., 1980, Quantitative relationships between Candida albicans in saliva and the clinical status of human subjects. J. Clin. Microbiol., 12: 475-476.

FAUX, J. A., STANLEY, V. C., BUCKLEY, H. R. \& PARTRIDGE, B. M., 1975, A comparison of different extracts of Candida albicans in agar gel double diffusion techniques. J. Immunol. Meth., 4: 235-247.

FINK, G. R., 1970, The biochemical genetics of yeast. In: Meth. Enzymol., 17: 59-78.

FREGERSLEV, S., 1969, A comparative study of the electrophoretic patterns of soluble proteins from some Candida species. Dansk Tidsskr. Farm., 43: 69-74.

GABRIEL-BRUNEAU, S. M. \& GUINET, R. M. F., 1984, Antigenic relationship among some Candida species studied by crossed-line immunoelectrophoresis: taxonomic significance. Int. J. System. Bact., 34: 227-236.
GATERMANN, S., HEESEMANN, J. \& LANFS, R., 1986, Identification of Candida albicans antigens recognized by sera of patients with candidiasis. Mycosen, 28: 343-354.

GLYNN, A. \& REID, J., 1969, Electrophoretic patterns of soluble fungal proteins and their possible use as taxonomic criteria in the genus Fusarium. Can. J. Bot., 47: 1823-1831.

GOMES, L. H., 1995, Avaliação de quatro métodos para caracterização de leveduras. Dissertação de Mestrado, Escola Superior de Agricultura, Luiz de Queiroz, USP.

GREENFIELD, R. A. \& JONES, J. M., 1981, Purification and characterization of a major cytoplasmic antigen of Candida albicans. Infect. Immun., 33: 469-477.

HALL, R., ZENTMYER, B. A. \& ERWIN, D. C., 1969, Approach to taxonomy of Phytophthora through acrylamide gel-electrophoresis of protein. Phytopathology, 59: $770-774$.

HALL, R., 1969, Molecular approaches to taxonomy of fungi. Botanical Review, 35: 285-304.

JOHNSTON, J. R., CONTOPOULOU, C. R. \& MORTIMER, R. K., 1988, Karyotyping of yeasts strains of several genera by field inversion gel electrophoresis. Yeast, 4: 191-198.

JORDAN, J. A., 1994, PCR identification of four medically important Candida species by using a single primer pair. J. Clin. Microbiol., 32: 2962-2967.

LANDAU, J. W., SHECHTER, Y. \& NEWCOMBER, V. D., 1968, Biochemical taxonomy of the dermatophytes. II. Numerical analysis of electrophoretic protein patterns. J. Invest. Dermatol., 51: 170-176.

LEHMANN, F. P., HSIAO, C. B. \& SALKIN, I. F., 1989, Protein and enzyme electrophoresis profiles of selected Candida species. J. Clin. Microbiol., 27: 400-404.

LAEMMLI, U. K., 1970, Cleavage of structural proteins during the assembly of the head of bacteriophage T4. Nature, 227: 680-685.

MAGEE, B. B. \& MAGEE, P. T., 1987, Electrophoretic karyotypes and chromosome numbers in Candida species. J. Gen. Microbiol., 133: 425-430.

MAGEE, P. T., RIKKERINK, E. H. A. \& MAGEE, B. B., 1988, Methods for the genetics and molecular biology of Candida albicans. Anal. Biochem., 175: 361-372.

MANNING, M. \& MITCHELL, T. G., 1980, Analysis of cytoplasmatic antigens of the yeast and mycelial phases of Candida albicans by two-dimensional electrophoresis. Infect. Immunol., 30: 484-495.

MEYER, W., LIECKFELDT, E., KUKLS, K., FREEDMAN, E. Z., BÖRNER, T. \& MITCHELL, T. G., 1993, DNA and PCR - fingerprinting in fungi. EXS., 67: 311-320.

MONOD, M., POCHET, S., BAUDRAZ-ROSSELET, F. \& FRENK, E., 1990, The identification of pathogenic yeast by electrophoretic analysis of their chromosomes. J. Med. Microbiol., 32: 129. 
MOORE, W. E. C., HASH, D. E., HOLDEMAN, L. V. \& CATO, E. P., 1980, Polyacrylamide slab gel electrophoresis of soluble proteins for studies of bacterial floras. Appl. Environ. Microbiol., 39: 900-907.

O'DONNELL, A. G., GOOD FELLOW, M. \& HAWKSWORTH, D. L., 1994, Theoretical and practical aspects of the quantification of biodiversity among microorganisms. Philos. Trabs. R. Soc. Lond. B. Biol. Sci., 348: 65-73

OKIRI, K. \& KAWAMOTO, I., 1995, Two-dimensional gel electrophoresis of ribosomal proteins as a novel approach to bacterial taxonomy: application to the genus Arthrobacter. Biosci. Biotechnol. Biochem., 62: 1679-1687.

RIMBAUD, P., BASTIDE, J. M. \& NAKAN, J., 1966, Étude de quelques espécies du genre Candida par immunofluorescence. Bull. Soc. Franç. Dermatol., 73: 275-278.

SHECHTER, Y., 1973a, Symposium on the use of electrophoresis in the taxonomy of algae and fungi. Bull. Torrey. Bot. Club., 100(5): 253-259.

SHECHTER, Y., 1973b, Electrophoresis and taxonomy of medically important fungi. Bull. Torrey. Bot. Club., 100: 277-287.

SHEN, H. D., CHOO K. B., TSAI, W. C., JEN, T. M., YEH, J. Y. \& HAN, S. H., 1988, Differential identification of Candida species and other yeasts by analysis of $\left({ }^{35} \mathrm{~S}\right)$ methionine-labeled polypeptide profiles. Anal. Biochem., 175: 548-551.

SPENCER, J. F. G. \& GORIN, P. A. J., 1969, Systematics of the genus Candida Berkhout: proton magnetic ressonance spectra of the mannans and mannosecontaining polysaccharides as an aid in classification. Antonie Van Leeuwenhoek, 35: 33-44.
SPENCER, J. F. T. \& GORIN, P. A. J., 1971, Systematics of the genus Candida Berkhout: proton magnetic ressonance spectra of the mannans and mannosecontaining polysaccharides as an aid in classification. Antonie Van Leeuwenhoek, 37: 75-88.

TSUCHIYA, T., FUKAZAWA, Y. \& KAWAKITA, S., 1965, Significance of serological studies on yeasts. Mycopathol. Mycol. Appl., 26: 1-15.

VAN UDEN, N. \& BUCKLEY, H., 1970, Genus Candida. Berkhout. pp. 893-1087. In: J. Lodder (ed.), The yeasts, a taxonomic study. North-Holland Publishing Co., Amsterdam, 2. ed.

VANCANNEYT, M., POT, B., HENNEBERT, G. \& KERSTERS, K., 1991, Differentiation of yeast species based on electrophoretic whole-cell protein patterns. System. Appl. Microbiol., 14: 22-23.

VANCANNEYT, M., VAN LERBERGE, E., BERNY, J. F., HENNERBERT, G. L. \& KERSTERS, K., 1992, The application of whole-cell protein electrophoresis for the classification and identification of basidiomycetous yeast species. Antonie Van Leeuwenhoek, 61: 6978.

VILJOEN, B. C., KOCH, J. L. F., MILlER, M. \& COETZEE, D. J., 1989, The value of orthogonalfield-alternation gel electrophoresis and other criteria in the delimitation of anamorphic-teleomorphic relations. System. Appl. Microbiol., 11: 305-311.

VILJOEN, B. C. \& KOCH, J. L. F., 1989, A taxonomic study of the yeast genus Candida Berkhout. System. Appl. Microbiol., 12: 91-102. 